\title{
First Description of the Generation of Human Schwann Cells Transfected With CRISPR Cas 9 and a Model of Metformin Mitochondrial Metabolism in Metachromatic Leukodystrophy
}

Nayibe Tatiana Sanchez Alvarez ( $\square$ nay.sanchez@mail.udes.edu.co )

Universidad de Santander, Facultad de Ciencias Médicas y de la Salud, Instituto de Investigación Masira https://orcid.org/0000-0001-8517-8331

\section{Paula Katherine Bautista-Niño}

Fundación Cardiovascular de Colombia: Fundacion Cardiovascular de Colombia

Juanita Trejos-Suárez

Universidad de Santander https://orcid.org/0000-0002-0697-3386

Norma Cecilia Serrano-Díaz

Fundación Cardiovascular de Colombia: Fundacion Cardiovascular de Colombia

\section{Research}

Keywords: Metachromatic leukodystrophy (MLD), metabolism, sulfatides, treatment

Posted Date: December 9th, 2021

DOI: https://doi.org/10.21203/rs.3.rs-1125555/v1

License: () (i) This work is licensed under a Creative Commons Attribution 4.0 International License. Read Full License 


\section{Abstract}

Background: Metachromatic leukodystrophy (MLD) is a neurological lysosomal deposit disease that has an impact on public health despite its low incidence in the population. Existing treatments are expensive and inefficient. Few reports in the literature on pathophysiological events related to enzyme deficiency and subsequent accumulation of sulfatides; therefore, the use of metformin as an alternative treatment was evaluated in vitro to counteract the effects.

Methodology: An experimental in vitro study that sought to determine the effect of the use of metformin on the accumulation of sulfates in glycolysis and mitochondrial function in an in vitro model of metachromatic leukodystrophy. Human Schwann cells (CSH) transfected with CRISPR Cas9 and without transfection were treated with different concentrations of sulfatides and metformin. Cell viability was evaluated by MTT and SYTOX Green; mitochondrial and glycolytic function by Seahorse XFe24, determination of reactive oxygen species (ROS) and cell death.

Results: In the MTT trials, we found that treatment with different concentrations of sulfates did not affect cell viability. Transfected CSH showed higher cell death and ROS production when exposed to $100 \mu \mathrm{M}$ sulfatides with a statistically significant difference $(p<0.001)$, compared to nontransfected CSH cells. Sulfatides at concentrations of 10 to $100 \mu \mathrm{M}$ affect mitochondrial bioenergetics as concentrations increase in transfected cells, in nontransfected cells they respond metabolically to exposure; Furthermore, transfected cells show a decrease in basal respiration and maximum respiration after being exposed to a concentration of $100 \mu \mathrm{M}$ of sulphates; however, in double treatment of these cells with both sulfates and Metformin, respiration also decreases. Maximum and normal mitochondrial respiratory capacity.

Conclusion: This research describes for the first time the generation of transfected CSH and the bioenergetic and mitochondrial effect of sulfates in Schwann cells, treatment with $500 \mu \mathrm{M}$ of Metformin restores metabolic activity of these cells and decreases ROS production, as well as prevention of cell death.

\section{Background}

Metachromatic leukodystrophy (MLD) is a lysosomal storage disease, classified as an inborn metabolism error, inherited in an autosomal recessive way, it implies progressive demyelination of the central nervous system (CNS) and peripheral nervous system (PNS), causing severe neurological symptoms (1-3). MLD is caused by different mutations in the ARSA gene found on chromosome 22q13.33, which consists of eight exons and encodes a 509 amino acid precursor $(4,5)$.

Currently, approximately 200 different types of mutations are known (6). Most of these are missense and, therefore, lead to deficient expression or structural damage to the enzyme Arylsulfatase A (ARSA) (7). ARSA is a lysosomal hydrolase that catalyzes the first step in the degradation of cerebroside 3 sulfate, one of the sulfatides found mainly in the white matter of the CNS and SNP $(8,9)$.

The overall incidence of the disease is not exactly known. However, the Orpha.net database reports an estimated prevalence of approximately 1 case per 625,000 live births and an incidence of 0.5 and $1 /$ 
50,000 (1). However, there is a lack of official records of people who have developed the disease or who are genetically at risk of developing it or transmitting it to their offspring (10).

Its great impact is due to the relentless deterioration of the patient's state of health. A person with a diagnosis of MLD must overcome the evolution of aging symptoms, psychiatric disorders, and loss of motor, intellectual, and social skills every day (11). To date, there is no readily available treatment or timely diagnosis scheme that controls the evolution of symptoms and prevents early death of the patient. The difficulty in developing an effective drug for the treatment of MLD is due to the poor understanding of the development of the disease, the few reports of molecular mechanisms, and the little interest that rare diseases generate in the pharmaceutical industry (2).

Based on information on the behavior of sulfatides in other types of metabolic systems, with the development of this project, it was demonstrated that the accumulation of sulfatides alters cellular metabolic processes such as glycolysis and mitochondrial function in myelinating SNP cells, such as Schwann cells with ARSA deficiency. Furthermore, we evaluate whether metformin helps reverse the effects of sulfate build-up.

\section{Methods}

\section{Study design}

This study was experimental in vitro and sought to determine the metformin effect of metformin use on the accumulation of sulfates in glycolysis and mitochondrial function in an in vitro model of metachromatic leukodystrophy.

\section{Cell culture}

The cell line used in this study was human Schwann cells isolated from the human spinal nerve (CSH; ScienCell Research Laboratories, USA). Cells were thawed and their viability was verified using $0.4 \%$ trypan blue dye in a Neubauer chamber and then cultured in Schwann cell medium (MCS, ScienCell Research Laboratories, USA) in a $5 \% \mathrm{CO}_{2}$ environment. under the conditions recommended by the manufacturer (12).

\section{Cell transfection}

Cultured CSH had a cell density between 30 and $70 \%$ for the assays 24 hours after seeding, which corresponded to approximately $2 \times 104$ cells per well in a 24 well plate (Corning ${ }^{\mathrm{TM}}$, Life Sciences, USA). With $500 \mu \mathrm{l}$ of MCS, the CRISPR Cas 9 assay was performed, in which the assembly of the ribonucleoprotein complex (RNP) was carried out in a 1.3: 1 ratio of personalized unique guide RNA containing a targeting sequence (sgRNA). GeneArt Platinum Cas9 nuclease (Life Technologies, USA), Lipofectamine ${ }^{\text {TM }}$ CRISPRMAX ${ }^{\text {TM }}$ Cas9 (Invitrogen, USA) was also used following the manufacturer's instructions. The sgRNA (GACCGUGGCCGAAGU) (Synthego, USA) was a 20-nucleotide sequence that is homologous to the exon 2 region of the ARSA gene and that directs the activity of the Cas9 nuclease. Additionally, the sgRNA sequence was used to align two or more sequences (https://blast.ncbi.nlm.nih.gov/Blast.cgi) with 
chromosome 22 of Homo Sapiens (NC_000022.11), for analysis. Positioning of Guide RNA Sequences and / or Primers.

The cells present in the 24-well plate were trypsinized, $50 \mu \mathrm{l}$ of the prepared mixture of sgRNA, reduced serum medium Opti-MEM ${ }^{\mathrm{TM}}$, Lipofectamine ${ }^{\mathrm{TM}}$ Cas9 Plus Reagent, GeneArt ${ }^{\mathrm{TM}}$ Platinum ${ }^{\mathrm{TM}}$ Cas9 nuclease, and Lipofectamine ${ }^{\text {TM }}$ CRISPRMAX were added to the well. TM transfection reagent according to the manufacturer's instructions (13). This was incubated at $37^{\circ} \mathrm{C}$ in a $5 \% \mathrm{CO} 2$ atmosphere for 3 days. After incubation, cell clonal expansion was performed by limiting the dilution, incubated at $37^{\circ} \mathrm{C}$ in an atmosphere of $5 \% \mathrm{CO} 2$ until a confluence of $80 \%$, and transferred to a $60 \mathrm{~mm} 3$ Petri plate, for subsequent performance of the essays.

\section{Reverse transcriptase polymerase chain reaction in real time (RT-qPCR)}

To quantify the expression of the ARSA gene in Schwann cells, before and after transfection with CRISPR Cas9. RNA extraction was performed using the TRIzol ${ }^{\circledR}$ method (Ambion, USA). The concentration and quality of the RNA were measured by spectrophotometry in NanoDrop 2000 (Thermo Fisher Scientific, USA), considering the ratio A260 / A280 1.75. RT-qPCR assays were performed with 2X Luna Universal Probe One-Step RT-qPCR (New England Biolabs, USA), $0.4 \mu \mathrm{M}$ Forward / reverse predesigned primers of TaqMan ${ }^{\circledR}$ gene expression assays (Life Technologies, USA) + fluorophore-labeled TaqMan probe FAM, 20X Luna WarmStart RT enzyme mix, and $100 \mathrm{ng} / \mu \mathrm{l}$ sample RNA for a final volume of $20 \mu \mathrm{L}$. Thermal cycling was carried out at $55^{\circ} \mathrm{C}$ for $20 \mathrm{~min}$ for reverse transcription, followed by $95^{\circ} \mathrm{C}$ for $5 \mathrm{~min}$ and then 45 cycles of $95^{\circ} \mathrm{C}$ for $15 \mathrm{~s}, 60^{\circ} \mathrm{C}$ for $45 \mathrm{~s}$, and a final elongation of $60^{\circ} \mathrm{C}$. for $5 \mathrm{~min}$, for a $69 \mathrm{bp}$ amplicon. The analysis of the results was carried out with the Bio-Rad CFX Manager 3.1 software version 3.1.1517.0823.

Analysis was carried out to determine the number of copies expressed in the ARSA gene of transfected cells compared to those without transfection, the relative quantification method was carried out, the endogenous gene used as a control was Glyceraldehyde-3-phosphate dehydrogenase (GADPH), with the formula:

$\triangle$ Ct Transfected cells $=\triangle C t$ ARSA gene $-\triangle C t$ GAPDH gene

$\Delta$ Ct Untransfected cells ct $=\Delta$ Ct ARSA gene $-\triangle$ Ct GAPDH gene

$\Delta \Delta c t=$ Transfected cells - Untransfected cells

$2^{\Delta \Delta c t}$

\section{Sequencing and bioinformatic analysis}


Before sequencing exon 2 of the ARSA gene, which allowed analysis of mutation in transfected cells, conventional PCR amplification was carried out in a final volume of $50 \mu \mathrm{L}, 2 X$ Master Mix Go Taq ${ }^{\circledR}$ Green (PROMEGA, USA), 10 nM Primer F 5'CCTACCTGGTCGTGGGAGTA3 ', Primer R 5'TGTCCCGCAGGGCCG3' and $100 \mathrm{ng}$ of DNA. The thermal cycle was carried out at $94^{\circ} \mathrm{C}$ for $5 \mathrm{~min}$, followed by 35 cycles of $94^{\circ} \mathrm{C}$ for $30 \mathrm{~s}, 60.5^{\circ} \mathrm{C} 40 \mathrm{~s}$, then $72^{\circ} \mathrm{C}$ for $30 \mathrm{~s}$ and $72{ }^{\circ} \mathrm{C}$ for 5 min. Electrophoresis was performed with a $1.0 \%$ agarose gel, at 80 volts for 45 minutes, to obtain a band of $256 \mathrm{bp}$. The PCR product was sequenced by Capillary Electrophoresis Sequencing at Macrogen Inc. (South Korea). Once the sequence was obtained, the assembly was performed with SeqMan Ultra-LaserGene Version 17 software (DNASTAR, USA) and its homology with exon 2 of the ARSA gene (NG_009260.2) was analyzed. With the observed differences, a high resolution three-dimensional theoretical structural model of the protein was built using the Swiss model server structure assessment tool (https://swissmodel.expasy.org/assess) using the human arylsulfatase protein sequence as a template. A (PDB ID: 1AUK).

\section{Cell Viability and Cytotoxicity}

Cell viability and proliferation were evaluated using the 3- (4,5-dimethylthiazol-2-yl) -2,5-diphenyltetrazo (MTT) bromide method (Alfa Aesar, UK). Cellular cytotoxicity made it possible to determine the concentrations of sulfatides and metformin for subsequent tests. In each trial, MCS was used as a treatment-free control, which served to normalize the results of the treatments.

$\mathrm{CSH}$ was seeded in 96-well plates at a density of $2 \times 104$ cells and incubated for 24 hours in an atmosphere of $5 \% \mathrm{CO} 2$ at $37^{\circ} \mathrm{C}$, then, in rows of triplicate, they were exposed to concentrations of $10,25,50$ and 100 $\mu \mathrm{M}$ of sulfatides (Matreya, USA), on the same plate in triplicate, they were exposed to $10,25,50,100,300$ and $1000 \mu \mathrm{M}$ of Metformin (1,1-Dimethylbig Unidos hydrochloride, 97\%, Acros Organics, Belgium). After 24 hours of posttreatment incubation, the medium was replaced with MTT dissolved in MCS at a concentration of $1 \mathrm{mg} / \mathrm{ml}$, for 1 hour in a $5 \% \mathrm{CO} 2$ atmosphere at $37^{\circ} \mathrm{C}$, after the time the MTT was removed from each well and replaced by $100 \mu \mathrm{L}$ of ACS grade dimethylsulfoxide (DMSO) (amresco®, USA). The color intensity was immediately measured by spectrophotometry on the Thermo Scientific Varioskan Flash plate reader (Thermo Fisher Scientific, USA), at a wavelength of $570 \mathrm{~nm}$. Additionally, photos were taken on the Eclipse Ti-S microscope, 10X magnification.

In the analyzes, the mean, the standard deviation, and the level of cytotoxicity were determined according to ISO 10993-5 of 2009, which highlights the classification of cytotoxicity according to the percentage of cell viability: 71 - 100\%: noncytotoxic, $<70 \%$ the compound has cytotoxic potential (14).

\section{Cell Death Assessment}

Nontransfected and transfected cells were cultured in 96-well plates at a density of 3x104 for 2 hours at 37

${ }^{\circ} \mathrm{C}$ in a 5\% CO2 atmosphere, for subsequent treatment with different concentrations of sulfatides and metformin dissolved in culture medium. After treatment, they were incubated for 24 hours at $37^{\circ} \mathrm{C}$ in a $5 \%$ $\mathrm{CO} 2$ atmosphere, on the day of the test cell death was determined by incubating the cells with $0.05 \mu \mathrm{M}$ of SYTOX'M Green nucleic acid stain (Invitrogen, USA) dissolved in MCS (MCS-SYTOX' ${ }^{\mathrm{TM}}$ ), a total of $100 \mu \mathrm{l}$ of MCS-SYTOX ${ }^{\mathrm{TM}}$ was added to each well, the plate was incubated for 15 minutes and subsequently the cells 
were observed in the Eclipse Ti-S fluorescence microscope (Nikon, Japan) (470 nm excitation, $523 \mathrm{~nm}$ emission). Similarly, a Thermo Scientific Varioskan Flash microplate reader (Thermo Fisher Scientific, USA) was used for the determination of fluorescence.

To determine dead cells, the average fluorescence of the wells in triplicate was used to calculate the ratio between the fluorescence of the control wells and the fluorescence of the wells containing lysed cells in the presence of $0.1 \%$ TRITON® X - 100 (amresco, USA) used as a positive control and as a negative control cell with MCS. Interpreting that, the greater the presence of fluorescence, the greater the cell death.

\section{Apoptosis}

Apoptosis was evaluated using the caspase $3 / 7$ and Annexin $V$ assay, essential to differentiate between the apoptosis and necrosis processes. The CSHs were seeded until they reached a confluence of $70 \%$. Caspase 3 and 7 activity was determined using the CellEvent ${ }^{\mathrm{TM}}$ Caspase-3 / 7 Green Flow Cytometry Assay Kit (Life Technologies, USA).

CSHs were treated with concentrations of $100 \mu \mathrm{M}$ of sulfatides and $500 \mu \mathrm{M}$ Metformin in culture medium, incubated for 24 hours at $37^{\circ} \mathrm{C}$, at a CO2 concentration of $5 \%$, the positive control used was $4 \mu \mathrm{M}$ Doxorubicin (Ebewe, Austria), the cytometry tubes each containing $1 \mathrm{ml}$ of cell suspension in phosphate buffered saline (PBS) were treated according to the manufacturer's instructions (15). Finally, the samples were analyzed using a $488 \mathrm{~nm}$ excitation filter and a 530/30 emission filter (green) for the CellEvent ${ }^{\mathrm{TM}}$ reagent and a 690/50 (red) filter for SYTOX ${ }^{\mathrm{TM}}$ AADvanced ${ }^{\mathrm{T}}$. This was read on FACScan III flow cytometry equipment (Becton Dickinson, USA). In which a minimum capture of 2,000 events was made.

Furthermore, the translocation of phosphatidyl-serine from the inner to the outer face of the membrane as a differentiator of apoptosis and mitochondrial membrane potential for living cells was evaluated using the MitoTracker ${ }^{\circledR}$ Red Kit and Alexa ${ }^{\circledR}$ Fluorine 488 Annexin V (Invitrogen, UK), for flow cytometry using FACScan III equipment (Becton Dickinson, USA) with a capture of 2,000 events, following the manufacturer's instructions (16). This assay is based on phosphatidylserine translocation and changes in mitochondrial membrane potential.

Apoptosis was induced in CSHs by treating them with concentrations of 10,25, 50 and $100 \mu \mathrm{M}$ of sulfatides and $500 \mu \mathrm{M}$ of Metformin and treated with $100 \mu \mathrm{M}$ of sulfatides and $500 \mu \mathrm{M}$ of Metformin, simultaneously. A negative control was prepared by incubating cells in the absence of the inducing agent and as a positive control for necrosis, cells were incubated with $4 \mu \mathrm{M}$ Doxorubicin (Ebewe, Austria).

Apoptotic cells show green fluorescence with decreased red fluorescence, and living cells show very little green fluorescence and high bright red fluorescence. These populations could be easily distinguished using a flow cytometer by measuring fluorescence in an emission spectrum at 530 and $585 \mathrm{~nm}$.

\section{Mitochondrial Bioenergetics}

Standardization of carbonylcyanuro-p-trifluoromethoxyphenylhydrazone the number of cells of carbonylcyanuro-p-trifluoromethoxyphenylhydrazone and the concentration of carbonylcyanuro-p- 
trifluoromethoxyphenylhydrazone (FCCP, ChemScene, USA) was carried out, against the response to this uncoupler, as recommended in the Mito Stress Test Kit protocol (Agilent Technologies, USA) (17), to guarantee optimal and reproducible culture conditions for comparability between the data and scientific results obtained with $\mathrm{CSH}$; for this reason, the selected population was 50,000 cells.

Nontransfected and transfected CSH were cultured for 2 hours in 24-well Seahorse plates (Agilent Technologies, USA) at a density of $5 \times 104$ in $100 \mu \mathrm{L}$ of MCS, treated with a volume of $150 \mu \mathrm{L}$ with concentrations of $10,25,50$ and $100 \mu \mathrm{M}$ of sulfatides and $500 \mu \mathrm{M}$ of Metformin for 24 hours at $37^{\circ} \mathrm{C}$ in $5 \% \mathrm{CO} 2$. Mitochondrial bioenergetic function was determined with the XF Cell Mito Stress Test kit to measure mitochondrial metabolism (Agilent Technologies, USA) in extracellular flux analysis with the Seahorse XFe24 Analyzer (Agilent Technologies, USA), following the manufacturer's instructions (17).

At the end of each assay, the protein concentration was determined using the Bradford method; To normalize the assay, the proteins were read at a wavelength of $590 \mathrm{~nm}$, using a Thermo Scientific Varioskan Flash plate reader (Thermo Fisher Scientific, USES).

One hour before starting the experiments, the CSHs were washed and changed to DMEM culture medium (Caisson Labs, USA) without buffers, which was supplemented with $1 \mathrm{mM}$ pyruvate, $10 \mathrm{mM}$ glutamine, and $5.5 \mathrm{mM}$ glucose, and the medium was adjusted to $\mathrm{pH}$ 7.4. After establishing the baseline of the oxygen consumption rate (OCR) and the extracellular acidification rate (ECAR), metabolic changes were measured with the addition of inhibitors, $1.5 \mu \mathrm{M}$ Oligomycin (ChemScene, USA) and $1 \mu \mathrm{M}$ of both FCCP and Antimycin A / Rotenone (ChemScene, USA).

\section{Mitochondrial Reactive Oxygen Species (ROS)}

Mitochondrial ROS levels were detected using the MitoSOX ${ }^{\mathrm{TM}}$ Red fluorescent probe (Invitrogen, USA), following the manufacturer's instructions (18), the fluorescent intensity was measured by an Eclipse Ti-S inverted microscope (Nikon, Japan) with a fluorescence lamp emission / excitation of 510/580 nm, respectively.

\section{Statistical analysis}

Statistical analyzes were performed with Graphpad Prism 8 (Graphpad Software, USA). All data are presented as mean \pm SEM. Statistical differences between two groups were analyzed using the $t$ test for unpaired data. If more than two groups were evaluated, the groups were analyzed using one-way analysis of variance (ANOVA) with the Bonferroni test. A value of $p *$ : $p<0.05, * *: p<0.01$, ***: $p<0.001$ was considered statistically significant.

\section{Results}

\section{Cell transfection}

Transfected cells were obtained using the CRISPR Cas9 system, modified for the ARSA gene, and all tests were based on the original sequence of the ARSA gene (Gene ID: 410), to have the two cell populations 
working (transfected and nontransfected).

\section{Reverse transcriptase polymerase chain reaction in real time (RT-qPCR)}

The expression of the gene was verified by PCR-qRT; It was shown that cells that had been transfected, the expression of the ARSA gene was Ct 42.78 versus cells without transfection with Ct 33.36. The expression of the ARSA gene was found to decrease by 183.5 copy numbers in transfected versus nontransfected cells.

\section{Sequencing and bioinformatic analysis}

The presence of the ARSA gene was verified in both transfected and nontransfected cells by conventional PCR. In the analysis of the amplified sequencing, a 99\% identity was found with the sequence of exon 2 of the ARSA gene (ID NG_009260.2), in which c.418del was evidenced, a mutation already reported by other authors as NM_000487. 6: c.418del (19).

Theoretically, this deletion generated a protein change (p.His140fs) (dbSNP: rs745884435) (20), H140 [CAT] > I140 [AT] and in molecular modeling of the three-dimensional structure of the protein to compare structural similarity, a difference in folding was evident when the amino acid change occurs in this position, Figure 1.

\section{Cell Viability and Cytotoxicity}

Cell viability was $100 \%$ in nontransfected Schwann cells that were exposed in different assays for 24 hours to concentrations of 10 to $100 \mu \mathrm{M}$ of sulfatides and 10 to $1000 \mu \mathrm{M}$ of metformin.

\section{Cell Death Assessment}

As transfected and nontransfected Schwann cells were exposed to increasing concentrations of 10, 25, 50 and $100 \mu \mathrm{M}$ of sulfates, cell death increased, although only a statistically significant difference of * $p<0.05$ was found in treatment. of $100 \mu \mathrm{M}$ between transfected and nontransfected Schwann cells, for which this concentration was defined to identify whether metformin mitigated cell death by accumulation of sulfates in transfected Schwann cells. Statistically significant differences of *: $p<0.05, * *$ : $p<0.01$, were observed in transfected cells in the three treatments, both with $100 \mu \mathrm{M}$ sulphates, and in combined treatment with sulfates and metformin, as well as in the population alone. treated with $500 \mu \mathrm{M}$ Metformin (Figure 2).

\section{Apoptosis}

In nontransfected Schwann cells, $100 \mu \mathrm{M}$ sulfatide concentration did not induce caspase $3 / 7$ activity as a measure of apoptotic or necrotic cell death. In transfected Schwann cells, the concentration of $100 \mu \mathrm{M}$ induced an increase in cell death due to necrosis; Furthermore, double treatment with sulfates and metformin potentiates the effect on the generation of apoptosis and necrosis in these cells.

Cellular apoptosis analysis by flow cytometry revealed that both transfected and nontransfected Schwann cells exposed to $100 \mu \mathrm{M}$ concentrations of sulphates; $100 \mu \mathrm{M}$ sulfatides $+500 \mu \mathrm{M}$ Metformin and only 500 
$\mu \mathrm{M}$ Metformin showed statistically significant differences between apoptotic cells and living cells (Figure $3)$.

\section{Mitochondrial Bioenergetics}

The ideal selection of FCCP was $0.5 \mu \mathrm{M}$ since it allowed identifying the maximum oxygen consumption and the basal respiration was not less than $20 \mathrm{pmol} / \mathrm{min} / \mu \mathrm{g}$. In the XF Cell Mito Stress Test Kit, it was found that since nontransfected Schwann cells were exposed to sulfatide concentrations of 10,25 , and 50 $\mu \mathrm{M}$, they were able to respond metabolically, as evidenced by the increase in maximum respiration; however, this response does not occur at the concentration of $100 \mu \mathrm{M}$ concentration, in which these cells decrease basal oxygen consumption, maximum respiration, and reserve capacity (Figure 4).

When comparing the results with the transfected Schwann cells, these cells show an increase in maximum respiration without any exposure to sulphates; however, as the concentration of sulphates increases, this respiration is affected, as well as their basal respiration (Figure 4).

Similarly, in the ECAR values it was observed that the transfected Schwann cells had an increase in this parameter compared to those that were nontransfected (Figure 5).

Differences in phenotypic energy maps were observed between the two groups of cells (Figure 6a, b), an increase in the use of the glycolytic pathway was observed in response to mitochondrial stressors, as observed in statistical analyzes of the energy phenotype (Figure 6). For nontransfected cells, the levels of ECAR stressed in the treatment of $10,25,50$ and $100 \mu \mathrm{M}$ of sulfates were $2.10 ; 1.95 ; 2.01$ and $1.81 \mathrm{mpH}$ / $\mathrm{min} / \mathrm{ug}$, respectively, and for transfected cells they were 4.34, 3.47, 3.47 and $2.41 \mathrm{mpH} / \mathrm{min} / \mathrm{ug}$, respectively.

\section{Metformin in Sulfatide Metabolism}

Nontransfected cells were found to be exposed to a concentration of $100 \mu \mathrm{M}$ of sulfates and metformin treatment did not affect mitochondrial respiration (Figure 7a); In contrast, in transfected cells, which did not have the ability to respond to exposure to sulfatides, a decrease was observed in both basal respiration and maximum mitochondrial respiration and in normal mitochondrial respiratory capacity and percentage (Figure 7c, d, e and f), simultaneous treatment with $100 \mu \mathrm{M}$ of sulfates and $500 \mu \mathrm{M}$ metformin improves mitochondrial energy yield in transfected cells (Figure 7b). This is an indication that mitochondrial functionality is affected at the expense of the accumulation of sulphates; despite this, ATP production continues in the two groups of cells.

The phenotypic profile presented by the transfected and nontransfected cells against Metformin was evaluated. Nontransfected cells showed an energetic phenotype (Figure 8a); unlike transfected cells that tended to be quiescent when exposed to $100 \mu \mathrm{M}$ of sulfates and those treated simultaneously with sulfates and metformin recovered the initial energy profile, cells that were only treated with metformin tend to be more glycolytic (Figure 8b). Transfected cells exposed to a concentration of $100 \mu \mathrm{M}$ of sulfates show metabolic disturbance.

\section{Mitochondrial reactive oxygen species (ROS)}


Statistically significant differences are observed between the two cell groups (Figure 9). Transfected cells exposed to the $100 \mu \mathrm{M}$ concentration of sulfates showed the production of mitochondrial superoxide anion.

Treatment with metformin at a concentration of $500 \mu \mathrm{M}$ prevents the appearance of mitochondrial superoxide anion in transfected cells (Figure 10).

\section{Discussion}

\section{CRISPR Cas9-mediated genetic modification}

MLD is a lysosomal storage disease that leads to accumulation of sulfates due to the deficiency of the lysosomal enzyme ARSA; therefore, it generates clinical manifestations characterized by progressive motor and cognitive deficiency. The severity of the clinical course of MLD is determined by residual ARSA activity, depending on the type of mutation (21).

Despite efforts to find an effective treatment in patients with MLD, there is no effective therapeutic procedure for this disease. Existing ones, such as bone marrow or cord blood transplantation, do not have the ability of the disease to prevent progression of the disease (6). Therefore, interest continues in the search for an alternative therapy to improve the quality of life of patients with MLD.

In this research, genetic modification was performed using CRISPR Cas 9 gene editing technology with lipid-based transfection technique, a mutation was generated in exon 2 of the ARSA gene in CSH (ScienCell Research Laboratories, USA), methodology not described so far in this type of cells.

The genetic modification found was corroborated with the variant reported in the Leiden Open Variation DataBase (LOVD3 Whole Genome Datasets) (22), the mutation is homologous to the one defined and registered since February 16, 2016 with the single nucleotide polymorphisms (SNP) rs745884435, registered at position chr22: 50627213 - 50627219, in this case the allele was a deletion of a Guanine base (delG) - NM_000487.6, forging a frame shift mutation reading (23), the variant was identified as probably pathological associated with infantile MLD, the generation of the mutation in Schwann cells allowed experimental in vitro simulation of what happened in Schwann cells of patients with MLD.

Analysis of the theoretical 3D structural model showed that deletion of the Guanine nucleotide generates a premature stop codon and therefore a nonfunctional protein, in which the amino acid Histidine at position 140 is modified by an isoleucine ( $\mathrm{H} 140 \mathrm{O})$ (7). The mutation found is correlated with the heterozygous variant used as a positive control in the identification of childhood MLD according to the study by McCreary et al., 2019 (24), a cohort study that included 60 children with suspected genetic neuroinflammation for which a sequencing panel directed at 257 genes was developed, in which a molecular diagnosis was verified in $20 \%$ of the patients, highlighting some unexpected genotype-phenotype associations and new pathogenic variants. 
With the construction of the model of transfected Schwann cells that lacked the full activity of the ARSA gene, the expression of the gene was evaluated by RT-qPCR, in which it was found that the said expression decreased compared to the number of copies expressed in the nontransfected cells; this indicates that the amino acid change significantly affects the structure and function of the ARSA protein. This agrees with that reported in the study by Guo et al., 2020, who described the overexpression of the ARSA gene in mutated or transformed cells, showing an improvement in the efficiency of the ARSA enzyme against the metabolism of sulfates (25-27).

\section{Cell Viability and Cytotoxicity}

ARSA is an enzyme responsible for the metabolization of the sphingolipid 3'-o-sulfogalactosylceramide, known as sulfatide, avoiding its intracellular accumulation in lysosomes, this lipid plays an important role in the CNS and SNP in the myelination process; therefore, a mutation in the gene that encodes this enzyme would lead to an imbalance in this process (28).

The concentrations selected in this study that did not affect cell viability in Schwann cells were those of 10, 25, 50 and $100 \mu \mathrm{M}$, selected based on studies by Blanqvist et al., 2011 (29), in which the profile was evaluated for the development of lysosulfatides in the brain of mutant mice without ARSA and in that of Dali et al., 2015, in which they found that the accumulation of sulfatides and lysosulfatides in nerves and cerebrospinal fluid (CSF) that provide a marker of disease only in the PNS, in this study they implemented the use of C16: 0 sulfatates (Matreya, Pleasant Gap, PA) in the range of 20 to $2000 \mathrm{ng} / \mathrm{mg}$ of dry tissue and $400 \mathrm{ng} / \mathrm{mg}$ of C12: 0 sulfatides (ISTD, Avanti Polar Lipids) $(30,31)$.

In this sense, when the concentrations were selected, we proceeded to evaluate what the effects were that the Schwann cells presented, both transfected and nontransfected, when exposed to different concentrations of selected sulfates. Cell viability of transfected Schwann cells was affected when exposed to a concentration of $100 \mu \mathrm{M}$ of sulfates. These data can be compared with the results obtained in studies in which they have shown that the observed phenotype of mice lacking the ARSA gene is correlated with high levels of sulfatides (32); also, Shaimardanova et al., 2020, Rosenberg et al., 2016, Beerepoot et al., 2019 , have verified that the presence of high concentrations of sulfatides in the CNS and SNP leads to demyelination processes due to damage to the myelin sheath that covers most of the nerve fibers $(21,33,34)$. This damage is influenced by the accumulation of nonmetabolized lipids within lysosomes, which can invade other cell organelles, leading to a secondary deficiency of other enzymes, triggering cell death (21).

Enzyme defects in lysosomes lead to the generation of lysosomal storage diseases such as MLD, these organelles are involved in a series of cellular processes such as apoptosis and necrosis $(35,36)$.

Schwann cells transfected when exposed to a concentration of $100 \mu \mathrm{M}$ of sulfatides generated necrosis; however, apoptosis was generated when they were simultaneously exposed to treatment with $100 \mu \mathrm{M}$ of sulfatides and $500 \mu \mathrm{M}$ of Metformin, it should be noted that each cell of the body has a different metabolism from each other and reacts depending on the need for the substrate they need. In this case, 
little has been elucidated about the physiological processes in MLD (37), in pancreatic beta cell sulfates at a concentration of $30 \mu \mathrm{M}$ significantly reduce apoptosis, cell leakage, and NO production (31).

Since the accumulation of metachromatic material in peripheral nerves was first reported in MLD, it has been shown that the metachromatic material consists of Schwann cells and endoneural macrophages that are filled with characteristic lysosomal inclusions of sulfates, also called inclusion bodies. (3. 4). The presence of sulfatides in these cells causes their death and therefore demyelination processes, leading to the appearance of symptoms in patients with MLD (34).

\section{Mitochondrial bioenergetics as a response to stress caused by mutations in the ARSA gene}

It is the first time that mitochondrial behavior has been described in living CSH (nontransfected cells and transfected cells); therefore, at the phenotypic level, the transfected cells as they are exposed to the concentrations of sulfates tend to be quiescent in contrast. of what was found in nontransfected cells that present an energy profile.

Consequently, what is found in the mitochondrial phenotype in which the transfected cell loses the ability to use the metabolic pathways of glycolysis and oxidative phosphorylation to satisfy its energy demands under stress conditions is correlated with what is found in the generation of ROS and necrosis. due to the same mitochondrial involvement (38).

\section{ROS Mitochondrial.}

When evaluating the global profile of reactive oxygen species in transfected Schwann cells, it was found that these cells generated greater superoxide production at the mitochondrial level than nontransfected cells, as cells were exposed to different concentrations of sulfates, with statistical significance; however, the use of metformin decreases this production.

The positive charge on the phosphonium group in MitoSOX Red selectively directs this cell permeable HE derivative to mitochondria, where it accumulates as a function of the mitochondrial membrane potential and exhibits fluorescence after oxidation and subsequent binding to mitochondrial DNA (39).

The generation of reactive oxygen species and reactive nitrogen species (ROS and RNS) is considered an integral process of cellular functioning in each organism. ROS and RNS include a number of chemicals of different reactivities, such as superoxide radical anion $(\mathrm{O} 2 \cdot)$, hydrogen peroxide $(\mathrm{H} 2 \mathrm{O} 2)$, peroxynitrite (ONOO-), hydroxyl radical $(\mathrm{OH})$, nitrogen dioxide radical ( $\mathrm{NO} 2)$, anion carbonate radical $(\mathrm{CO} 3 \cdot$ ) among others. ROS and RNS have been proposed to play an important role in regulatory mechanisms, the transmission of biochemical signals, and in the defense response against microorganisms; however, their excessive production and / or insufficient detoxification can lead to oxidative / nitrative damage through ROS and RNS that induce the modification of cellular components, including proteins, lipids, and DNA (40). 
Oxidative stress has been well described as an imbalance in the generation and neutralization of ROS and RNS in living organisms, leading to overproduction of ROS and RNS in steady state. Oxidative stress alters redox homeostasis in various diseases (eg atherosclerosis, cancer, neurodegenerative diseases, myocardial infarction), which can cause irreversible damage and exacerbation of the disease state $(41,42)$.

In the same way, defective autophagy leads to the accumulation of mitochondria within the cell, which can generate the release of ROS as a result of exposure to conditions of cellular stress (43).

\section{Metformin as a therapeutic potential in the metabolic enhancement of sulfatide accumulation and glycolysis in transfected human Schwann cells.}

Treatment of MLD remains enigmatic; however, efforts must continue to focus on finding an alternative treatment that improves the living conditions of patients. In this case, the use of metformin is proposed as a treatment to improve and reduce the effects at the mitochondrial level caused by the accumulation of sulfates.

Metformin is a class of plant-based drugs that has been widely used to treat diabetes since the 1950s (44). This drug was chosen because, despite being the first choice biguanide for the treatment of type 2 diabetes, it has been widely proposed as an alternative treatment for other pathologies such as Parkinson's (45), Alzheimer's (46), liver diseases (47), multiple sclerosis (48), among others; all because it has antioxidant, anti-inflammatory, antiapoptosis, and antitumor properties (49-51). In vivo, metformin has been found to cross the blood-brain barrier and accumulate in the brain (52).

Metformin has been shown to act by both AMP-activated protein kinase (AMPK) and AMPK-independent mechanisms; by inhibiting mitochondrial respiration, but also by inhibiting mitochondrial glycerophosphate dehydrogenase and a mechanism that involves the lysosome (47,53). Labuzek et al., 2010, determined that Metformin modified lysosomal pH, therefore, it generates activation of lysosomal enzymes in microglia (52).

Treatment of the transfected cells with Metformin caused an increase in maximum mitochondrial respiration as shown in normalization of the seahorse XFe Mito stress test compared to the decrease in this parameter evidenced in the transfected and treated with sulfates, which indicates that this drug shows an improvement in the response of mitochondrial metabolism. Similarly, a reduction in the generation of intracellular and mitochondrial ROS was evidenced.

\section{Conclusions}

The generation of transfected Human Schwann cells is described for the first time and the presence of sulfatides affects them metabolically at the mitochondrial level. Treatment with $500 \mu \mathrm{M}$ Metformin reduces 
ROS generation generally in the cell and at the mitochondrial level. Metformin improves mitochondrial bioenergetic performance in cells with mutations in the ARSA gene.

\section{Abbreviations}

AMPK: AMP-activated protein kinase

ANOVA: One-way analysis of variance

ATP: Adenosine triphosphate

CNS: Central Nervous System

$\mathrm{CO} 3 \cdot$ Anion carbonate radical

CRISPR Cas9: Short Palindromic Repetitions Grouped and Regularly Spaced

CSF: Cerebrospinal fluid

CSH: Human Schwann cells

DMSO: Dimethylsulfoxide

ECAR: Extracellular acidification rate

FCCP: Carbonylcyanuro-p-trifluoromethoxyphenylhydrazone

GalC: Galactosylceramide

H2O2: Hydrogen peroxide

LOVD3: Leiden Open Variation DataBase

MCS: Cultured in Schwann cell medium

MLD: Metachromatic Leukodystrophy

MTT: 3- (4,5-dimethylthiazol-2-yl) -2,5-diphenyltetrazol

NO2: Nitrogen dioxide radical

$02 \cdot:$ Superoxide radical anion

OCR: Oxygen consumption rate

$\mathrm{OH}:$ Hydroxyl radical

ONOO-: Peroxynitrite 
PBS: Phosphate buffered saline

PNS: Peripheral Nervous System

RNP: Ribonucleoprotein Complex

RNS: Reactive nitrogen species

ROS: Mitochondrial Reactive Oxygen Species

RT-qPCR: Reverse transcriptase polymerase chain reaction in real time

sgRNA: Single-guide RNA

\section{Declarations}

\section{Ethic approval and consent to participate}

Our study was presented to the Ethics and Research Committee of the Cardiovascular Foundation of Colombia, as stated in Minute 375 of 2015. However, it did not require the use of informed consent, because it did not work with cells obtained directly from patients, but with reference cells from the ScienCell repository.

\section{Consent for publication}

Not applicable

\section{Availability of data and materials}

The datasets generated and/or analyzed during the current study are not publicly available due because some of them are part of other studies that are in the finalization phase but are available from the corresponding author on reasonable request.

\section{Competing interests}

The authors declare that they have no competing interests.

\section{Funding}

This project was funded by the macroproject entitled 'Metabolism of Sulfates, Glycolysis and Mitochondrial Function in Metachromatic Leukodystrophy' in the Call for Research Projects in Basic Sciences, 712-2015, of Minciencias. Whose main researcher is Dr. Norma C. Serrano. The Universidad de Santander financed the publication of this article.

\section{Authors' contributions}


PBN and NSD Conceptualization, Funding acquisition, Project administration, Resources. PBN, NSD and JTS Supervision, Validation. NTSA and JTS Data curation, Formal analysis, Investigation, Methodology. All authors reviewed the manuscript and approved the final manuscript before submission. All authors read and approved the final manuscript.

\section{Acknowledgements}

Special thanks to the Ministry of Science, Technology, and Innovation for funding macroproject No. 656671249950 Calls for funding 712-2015 and 745-2016. To the Cardiovascular Foundation of Colombia, the Laboratory for Biomedical and Biotechnological Research - LIBB and Mike Alexander Celis Rodríguez, for their support and advice on flow cytometry analysis.

\section{References}

1. Doherty K, Frazier SB, Clark M, Childers A, Pruthi S, Wenger DA, et al. A closer look at ARSA activity in a patient with metachromatic leukodystrophy. Mol Genet Metab Rep. 2019; 19: 100460.

2. Sanchez-Alvarez NT, Bautista-Niño PK, Trejos-Suárez J, Serrano-Diaz NC. Metachromatic leukodystrophy: Diagnosis and treatment challenges. 2021;3(3):2083-90.

3. Bonkowsky JL, Wilkes J, Bardsley T, Urbik VM, Stoddard G. Association of Diagnosis of leukodystrophy with race and Ethnicity Among Pediatric and Adolescent Patients. JAMA Netw Open. 2018; 1 (7): e185031-e185031.

4. Özkan A, Özkara HA. Metachromatic leukodystrophy: Biochemical characterization of two (p.307Glu $\rightarrow$ Lys, p.318Trp $\rightarrow$ Cys) arylsulfatase A mutations. Intractable Rare Dis Res. 2016; 5 (4): 280-3.

5. Niida Y, Kuroda M, Mitani Y, Yokoi A, Ozaki M. Paternal uniparental isodisomy of chromosome 22 in a patient with metachromatic leukodystrophy. J Hum Genet. 2012; 57 (10): 687-90.

6. $\mathrm{HGMD} \circledast$ gene result [Internet]. [cited $2021 \mathrm{Jul} 12$ ]. Available at: http://www.hgmd.cf.ac.uk/ac/gene.php?gene=ARSA

7. Golchin N, Hajjari M, Malamiri RA, Aminzadeh M, Mohammadi-asl J, Golchin N, et al. Identification of a novel mutation in ARSA gene in three patients of an Iranian family with metachromatic leukodystrophy disorder. Genet Mol Biol. 2017; 40 (4): 759-62.

8. Gieselmann V. Metachromatic leukodystrophy: genetics, pathogenesis, and therapeutic options. Acta Pediatrics. 2008; 97 (s457): 15-21.

9. Virgens MYF, Pol-Fachin L, Verli H, Saraiva-Pereira ML. Effects of glycosylation and pH conditions on the dynamics of human arylsulfatase A. J Biomol Struct Dyn. 2014; 32 (4): 567-79.

10. Bonkowsky JL, Wilkes J, Ying J, Wei W-Q. Novel and known morbidities of leukodystrophies identified using a phenome-wide association study. Neurol Clin Pract. 2020; 10 (5): 406-14.

11. Harrington M, Hareendran A, Skalicky A, Wilson H, Clark M, Mikl J. Assessing the impact on caregivers caring for patients with rare pediatric lysosomal storage diseases: development of the caregiver impact questionnaire. J Patient-Rep Outcomes. 2019; 3: 44. 
12. ScienCell Research Laboratories, inc. I ScienCell Research Laboratories [Internet]. [cited 2020 Jun 30]. Available at: https://www.sciencellonline.com/

13. Lipofectamine ${ }^{\mathrm{TM}}$ CRISPRMAX ${ }^{\mathrm{TM}}$ Cas 9 transfection reagent [Internet]. [cited 2021 Sep 6]. Available at: https://www.thermofisher.com/order/catalog/product/CMAX00001?ef_id=Cj0KCQjwNaJBhDsARIsAAja6dNqNGEdkc8MjF80Nj76-q9QsHquOukpnvfgllCad4YZVLYRpmbcNQaAtIrEALw_wcB:G:s\&s_kwcid=AL!3652!3!361702390051!e!!g!!lipofectamine ?\% 20crisprmax \& cid = bid_clb_tfx_r01_co_cp0000_pjt0000_bid00000_0se_gaw_bt_pur_con \& gclid = Cj0KCQjw-NaJBhDsARIsAAja6dNqNGEdkc8MjF80Nj76-q9QsHquOukpnvfgllCad4YZVLYRpmbcNQaAtIrEALw_wcB \# / CMAX00001 ef_id = CjOKCQjwNaJBhDsARIsAAja6dNqNGEdkc8MjF80Nj76-q9QsHquOukpnvfgllCad4YZVLYRpmbcNQaAtIrEALw_wcB: g: s \& s_kwcid = A THE 36523361702390051 e !! g !! lipofectamine\% 20crisprmax \& cid = bid_clb_tfx_r01_co_cp0000_pjt0000_bid00000_0se_gaw_bt_pur_con \& gclid =!!!! CjOKCQjw-NaJBhDsARIsAAja6dNqNGEdkc8MjF80Nj76-q9QsHquOukpnvfgllCad4YZVLYRpmbcNQaAtIrEALw_wcB

14. ISO-10993-5-2009.pdf [Internet]. [cited 2021 Jul 12]. Available at: http://nhiso.com/wpcontent/uploads/2018/05/ISO-10993-5-2009.pdf

15. CellEvent ${ }^{\mathrm{TM}}$ Caspase-3/7 Green Flow Cytometry Assay Kit [Internet]. [cited 2021 Sep 6]. Available at: https://www.thermofisher.com/order/catalog/product/C10427\#/C10427

16. Mitochondrial Membrane Potential Apoptosis Kit, with Mitotracker ${ }^{\mathrm{TM}}$ Red \& Annexin V Alexa Fluor ${ }^{\mathrm{TM}}$ 488, for flow cytometry [Internet]. [cited 2021 Sep 6]. Available at: https://www.thermofisher.com/order/catalog/product/V35116

17. User guide for the Seahorse XF cell mito stress test kit. [Internet]. [cited 2021 Sep 6]. Available at: https://www.agilent.com/cs/library/usermanuals/public/XF_Cell_Mito_Stress_Test_Kit_User_Guide.pdf

18. MitoSOX ${ }^{\mathrm{T}}$ Red Mitochondrial Superoxide Indicator, for live-cell imaging [Internet]. [cited $2021 \mathrm{Sep}$ 7]. Available at: https://www.thermofisher.com/order/catalog/product/M36008

19. VCV000370472.1 - ClinVar - NCBI [Internet]. [cited 2021 Sep 23]. Available at: https://www.ncbi.nlm.nih.gov/clinvar/variation/370472/

20. rs745884435 RefSNP Report - dbSNP - NCBI [Internet]. [cited 2021 Sep 23]. Available at: https://www.ncbi.nlm.nih.gov/snp/rs745884435?vertical_tab=true\#publications

21. Shaimardanova AA, Chulpanova DS, Solovyeva VV, Mullagulova Al, Kitaeva KV, Allegrucci C et al. Metachromatic leukodystrophy: Diagnosis, modeling, and treatment approaches. Front Med. 2020; 7. 576221.

22. ARSA gene homepage - Global Variome shared LOVD [Internet]. [cited 2020 May 31]. Available at: https://databases.lovd.nl/shared/genes/ARSA

23. ARSA Gene Home Page - Global Variome Shared LOVD [Internet]. [cited 2020 May 30]. Available at: https://databases.lovd.nl/shared/genes/ARSA

24. McCreary D, Omoyinmi E, Hong Y, Mulhern C, Papadopoulou C, Casimir M et al. Development and validation of a targeted next-generation sequencing gene panel for children with neuroinflammation. JAMA Netw Open. 2019; 2 (10): e1914274. 
25. Cesani M, Lorioli L, Grossi S, Amico G, Fumagalli F, Spiga I, et al. Mutation Update of ARSA and PSAP Genes Causing Metachromatic Leukodystrophy. Hum Mutat. 2016; 37 (1): 16-27.

26. Doerr J, Böckenhoff A, Ewald B, Ladewig J, Eckhardt M, Gieselmann V, et al. Arylsulfatase A overexpressing human iPSC-derived neural cells reduces the storage of CNS sulfatide in a mouse model of metachromatic leukodystrophy. Mol Ther. 2015; 23 (9): 1519-31.

27. Kawabata K, Migita M, Mochizuki H, Miyake K, Igarashi T, Fukunaga Y, et al. Ex vivo cell-mediated gene therapy for metachromatic leukodystrophy using neurospheres. Brain Res. 2006; 1094 (1): 13-23.

28. Takahashi T, Suzuki T. Role of sulfatide in normal and pathological cells and tissues. J Lipid Res. 2012; 53 (8): 1437-50.

29. Blomqvist M, Gieselmann V, Månsson J-E. Accumulation of lysosulfatide in the brain of arylsulfatase A-deficient mice. Lipids Health Dis. 2011; 10 (1): 28.

30. Dali C, Barton NW, Farah MH, Moldovan M, Månsson J-E, Nair N, et al. Sulfatide levels correlate with severity of neuropathy in metachromatic leukodystrophy. Ann Clin Transl Neurol. 2015; 2 (5): 518-33.

31. Roeske-Nielsen A, Dalgaard LT, Månsson J-E, Buschard K. The glycolipid sulfatide protects insulinproducing cells against cytokine-induced apoptosis, a possible role in diabetes. Diabetes Metab Res Rev. 2010; 26 (8): 631-8.

32. Ramakrishnan H, Hedayati KK, Lullmann-Rauch R, Wessig C, Fewou SN, Maier H et al. Increasing sulfatide synthesis in myelin-derived cell cultures from Arylsulfatase A-deficient mice causes demyelination and neurological symptoms reminiscent of human metachromatic leukodystrophy. J Neurosci. 2007. 29; 27 (35): 9482-90.

33. Rosenberg JB, Kaminsky SM, Aubourg P, Crystal RG, Sondhi D. Gene therapy for metachromatic leukodystrophy. J Neurosci Res. 2016; 94 (11): 1169-79.

34. Beerepoot S, Nierkens S, Boelens JJ, Lindemans C, Bugiani M, Wolf NI. Peripheral neuropathy in metachromatic leukodystrophy: current status and future perspective. Orphanet J Rare Dis. 2019; 14: 240.

35. Harlan, FK, Lusk, JS, Mohr, BM, Guzikowski, AP, Batchelor, RH, Jiang, Y et al. Fluorogenic substrates to visualize acidic organelle enzyme activities. PLoS ONE. 2016; 11 (5): e0156312.

36. Sevin C, Aubourg P, Cartier N. Enzyme, cell, and gene-based therapies for metachromatic leukodystrophy. J Inherit Metab Dis. 2007; 30 (2): 175-83.

37. Frati G, Luciani M, Meneghini V, De Cicco S, Ståhlman M, Blomqvist M, et al. Human iPSC-based models highlight defective glial and neuronal differentiation from neural progenitor cells in metachromatic leukodystrophy. Cell Death Dis. 2018; 9 (6): 698.

38. Xu Y, Shen J, Ran Z. Emerging views of mitophagy in immunity and autoimmune diseases. Autophagy. 2020; 16 (1): 3-17.

39. Mukhopadhyay P, Rajesh M, Haskó G, Hawkins BJ, Madesh M, Pacher P. Simultaneous detection of apoptosis and mitochondrial superoxide production in live cells by flow cytometry and confocal microscopy. Nat Protoc. 2007; 2 (9): 2295-301. 
40. Buonocore G, Perrone S, Tataranno ML. Oxygen toxicity: Chemistry and biology of reactive oxygen species. Semin Fetal Neonatal Med. 2010; 15 (4): 186-90.

41. Dębski D, Smulik R, Zielonka J, Michałowski B, Jakubowska M, Dębowska K, et al. Mechanism of oxidative conversion of Amplex ${ }^{\circledR}$ Red to resorufin: pulse radiolysis and enzymatic studies. Free Radic Biol Med. 2016; 95: 323-32.

42. Panizzi P, Nahrendorf M, Wildgruber M, Waterman P, Figueiredo J-L, Aikawa E, et al. Oxazine Conjugated Nanoparticle Detects In Vivo Hypochlorous Acid and Peroxynitrite Generation. J Am Chem Soc. 2009; 131 (43): 15739-44.

43. Simonaro CM. Lysosomes, Lysosomal Storage Diseases, and Inflammation. J Inborn Errors Metab Screen. 2016; 4: 2326409816650465.

44. Flory J, Lipska K. Metformin in 2019. JAMA. 2019; 321 (19): 1926-7.

45. Mor DE, Sohrabi S, Kaletsky R, Keyes W, Tartici A, Kalia V, et al. Metformin rescues Parkinson's disease phenotypes caused by hyperactive mitochondria. Proc Natl Acad Sci U S A. 2020; 117 (42): 26438-47.

46. Markowicz-Piasecka M, Sikora J, Szydłowska A, Skupień A, Mikiciuk-Olasik E, Huttunen KM. Metformin - A Future Therapy for Neurodegenerative Diseases Pharm Res. 2017; 34 (12): 2614-27.

47. Rena G, Hardie DG, Pearson ER. The mechanisms of action of metformin. Diabetology. $2017 ; 60$ (9): 1577-85.

48. Dziedzic A, Saluk-Bijak J, Miller E, Bijak M. Metformin as a Potential Agent in the Treatment of Multiple Sclerosis. Int J Mol Sci. 2020; 21 (17): 5957.

49. Fang M, Jiang H, Ye L, Cai C, Hu Y, Pan S, et al. Metformin treatment after the hypoxia-ischemia attenuates brain injury in newborn rats. Oncotarget. 2017; 8 (43): 75308-25.

50. Rocha-Ferreira E, Hristova M. Plasticity in the Neonatal Brain following Hypoxic-Ischemic Injury. Neural Plast. 2016; 2016: 4901014.

51. Eikawa S, Nishida M, Mizukami S, Yamazaki C, Nakayama E, Udono H. Immune-mediated antitumor effect by type 2 diabetes drug, metformin. Proc Natl Acad Sci U S A. 2015; 112 (6): 1809-14.

52. Labuzek K, Liber S, Gabryel B, Adamczyk J, Okopień B. Metformin increases phagocytosis and acidifies lysosomal / endosomal compartments in AMPK-dependent manner in rat primary microglia. Naunyn Schmiedebergs Arch Pharmacol. 2010; 381 (2): 171-86.

53. Rena G, Pearson ER, Sakamoto K. Molecular mechanism of action of metformin: old or new insights? Diabetology. 2013; 56

\section{Figures}


A

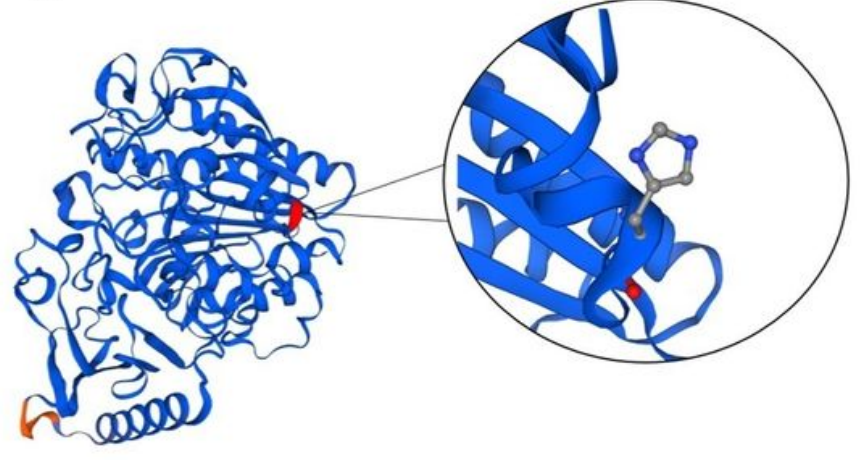

B

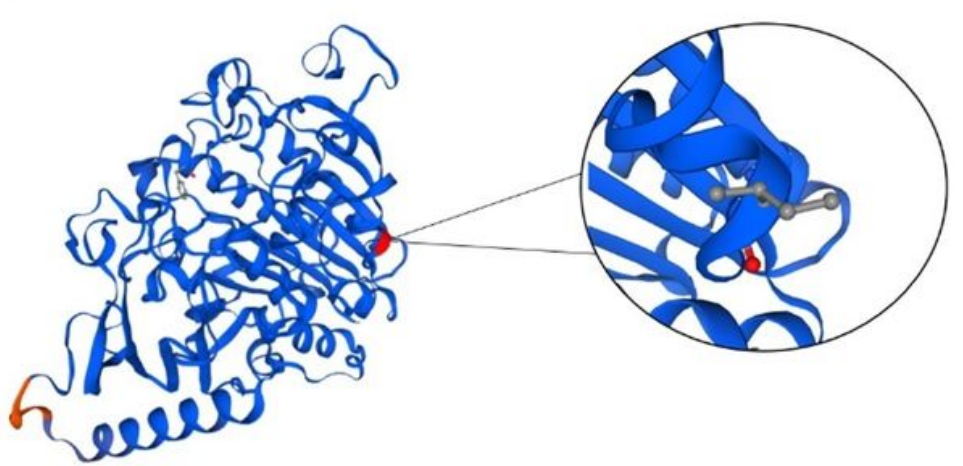

\section{Figure 1}

In silico modeling of the protein. Theoretical structure of the protein in 3D, A. ARSA protein from nontransfected Schwann cells (H140), B. ARSA protein from transfected Schwann cells (1140). 


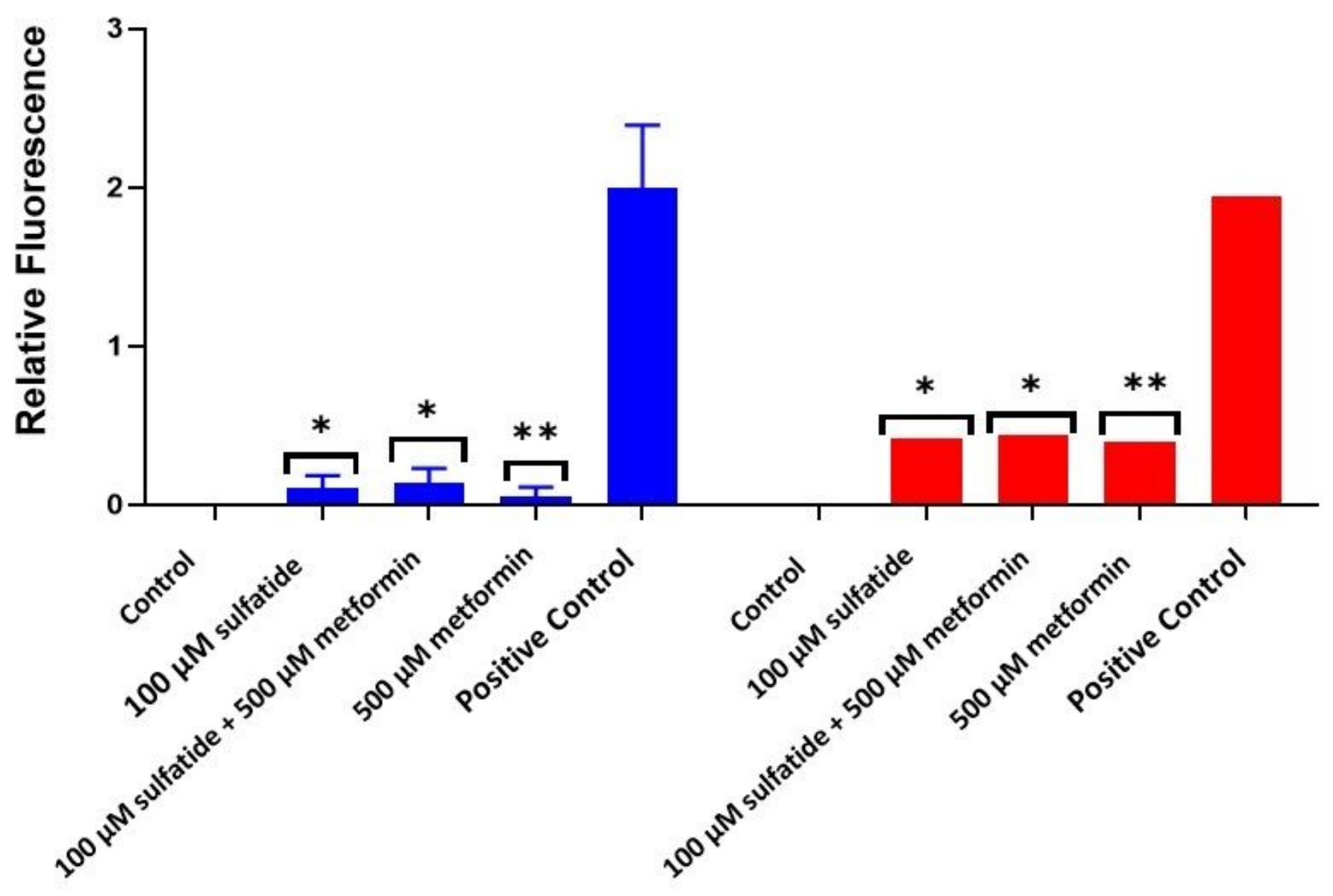

\section{Treatments}

\section{Figure 2}

Cell Death in Transfected and Nontransfected Schwann Cells. Relative fluorescence of transfected and nontransfected Schwann cells at different concentrations of SYTOX Green stained sulfates. 


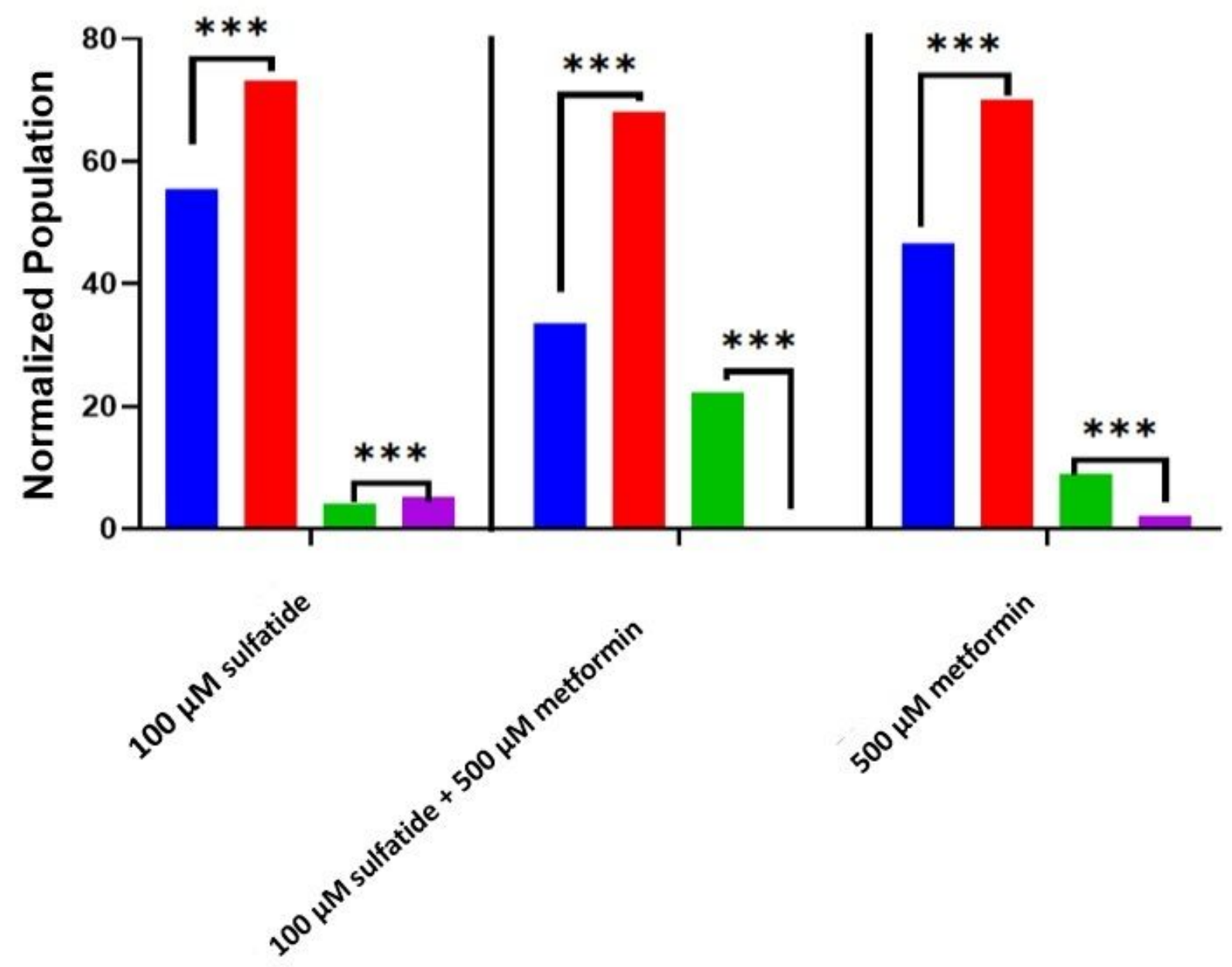

Treatments

Figure 3

Cellular apoptosis by flow cytometry. Data are representative of two independently conducted trials. ${ }^{\star \star \star}$ : $p$ $<0.001$. 

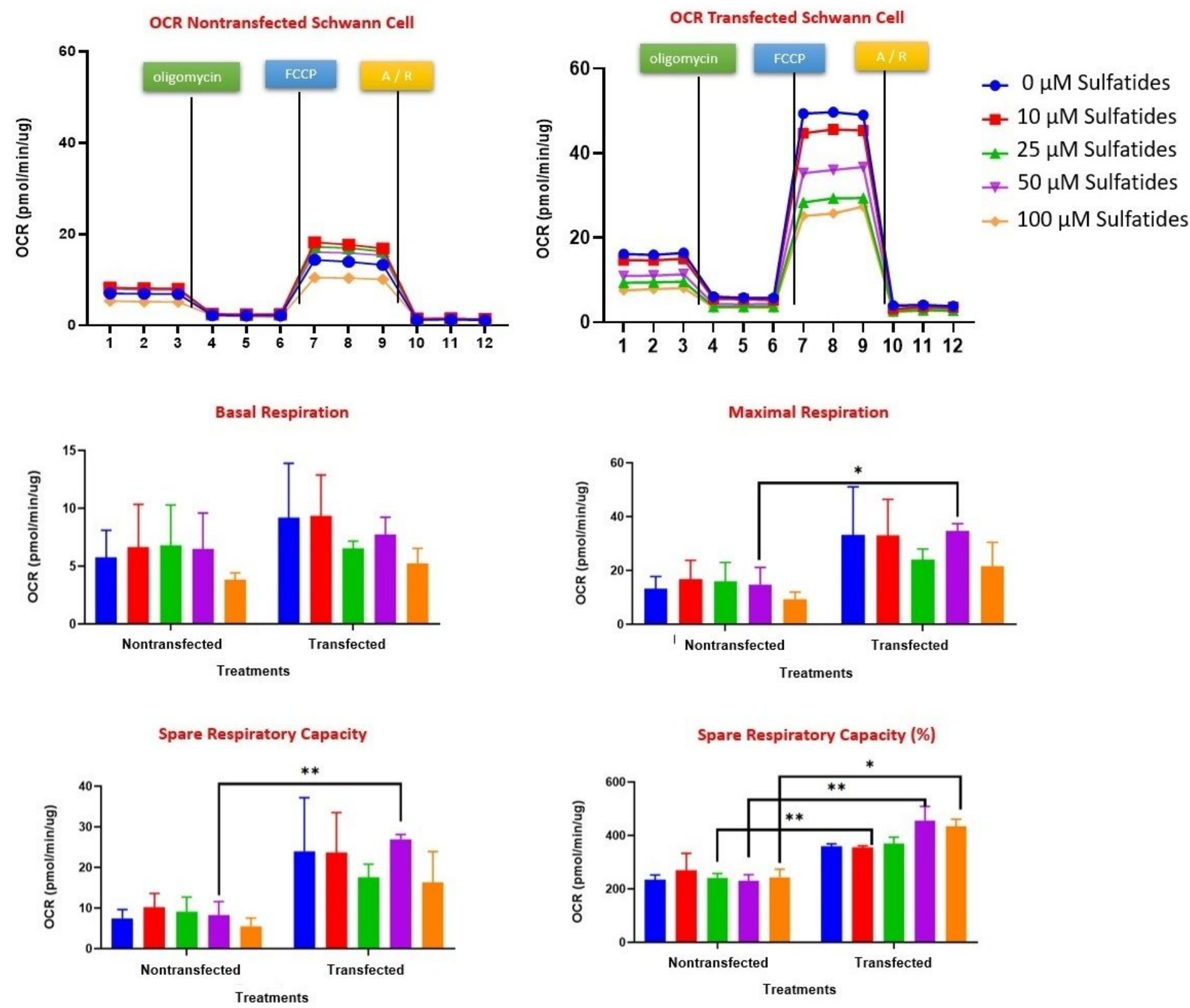

Figure 4

Mito Stress test, OCR in transfected and nontransfected Schwann cells. Data are representative of two independently conducted trials. *: $p<0.05, * *$ : $p<0.01$, ***: $p<0.001$. 
A

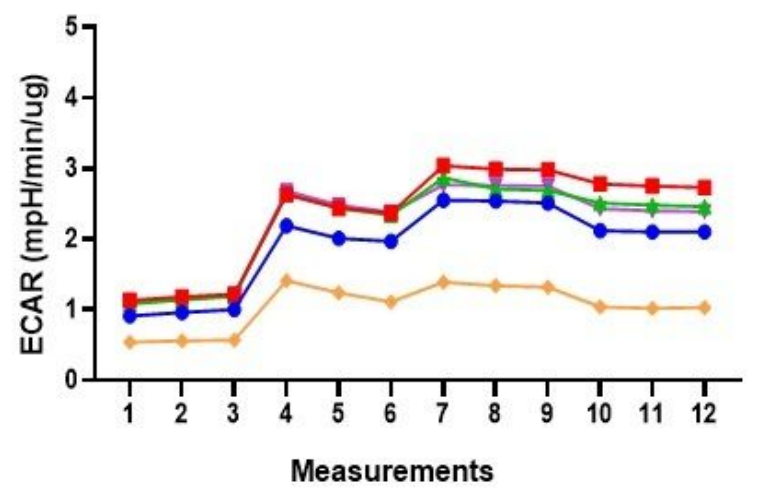

B

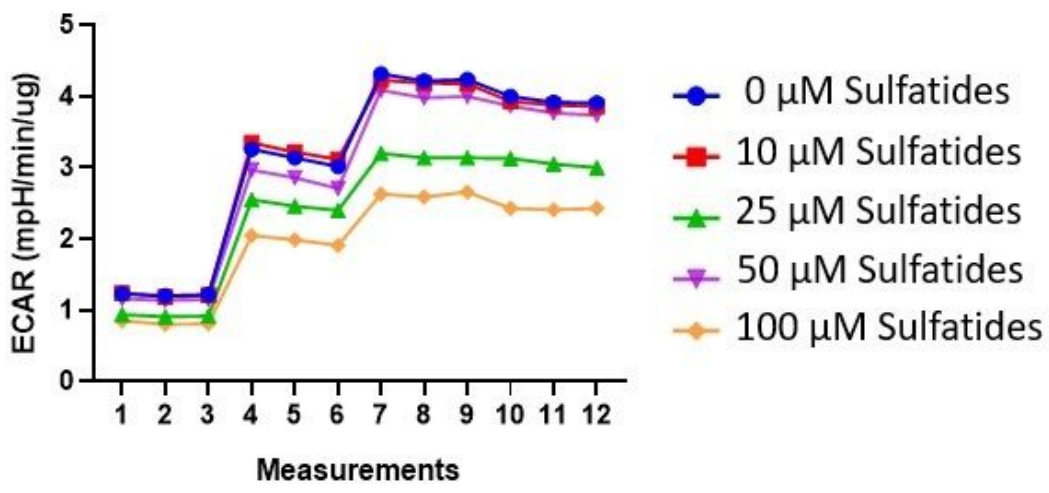

Figure 5

Mito Stress test, ECAR of transfected and nontransfected cells. A. Nontransfected Schwann cells. B. Transfected Schwann cells.

A XF Cell Energy Phenotype

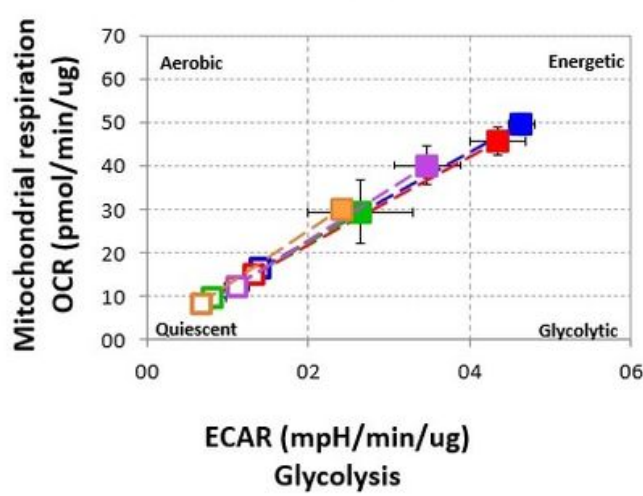

B

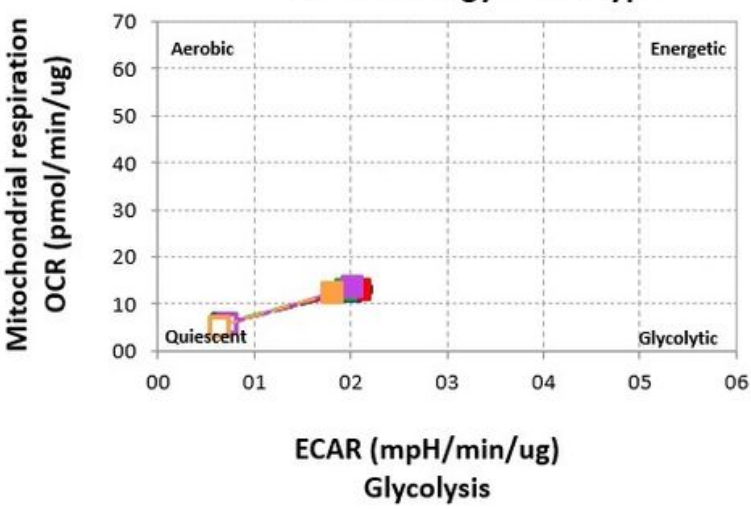

$\rightarrow 0 \mu \mathrm{M}$ Sulfatides

- $10 \mu \mathrm{M}$ Sulfatides

$\star 25 \mu \mathrm{M}$ Sulfatides

$\rightarrow 50 \mu \mathrm{M}$ Sulfatides

$\rightarrow 100 \mu \mathrm{M}$ Sulfatides

\section{Figure 6}

Energetic phenotype in transfected and nontransfected Schwann cells, treated with sulfates. A. Nontransfected Schwann cells. B. Transfected Schwann cells. 

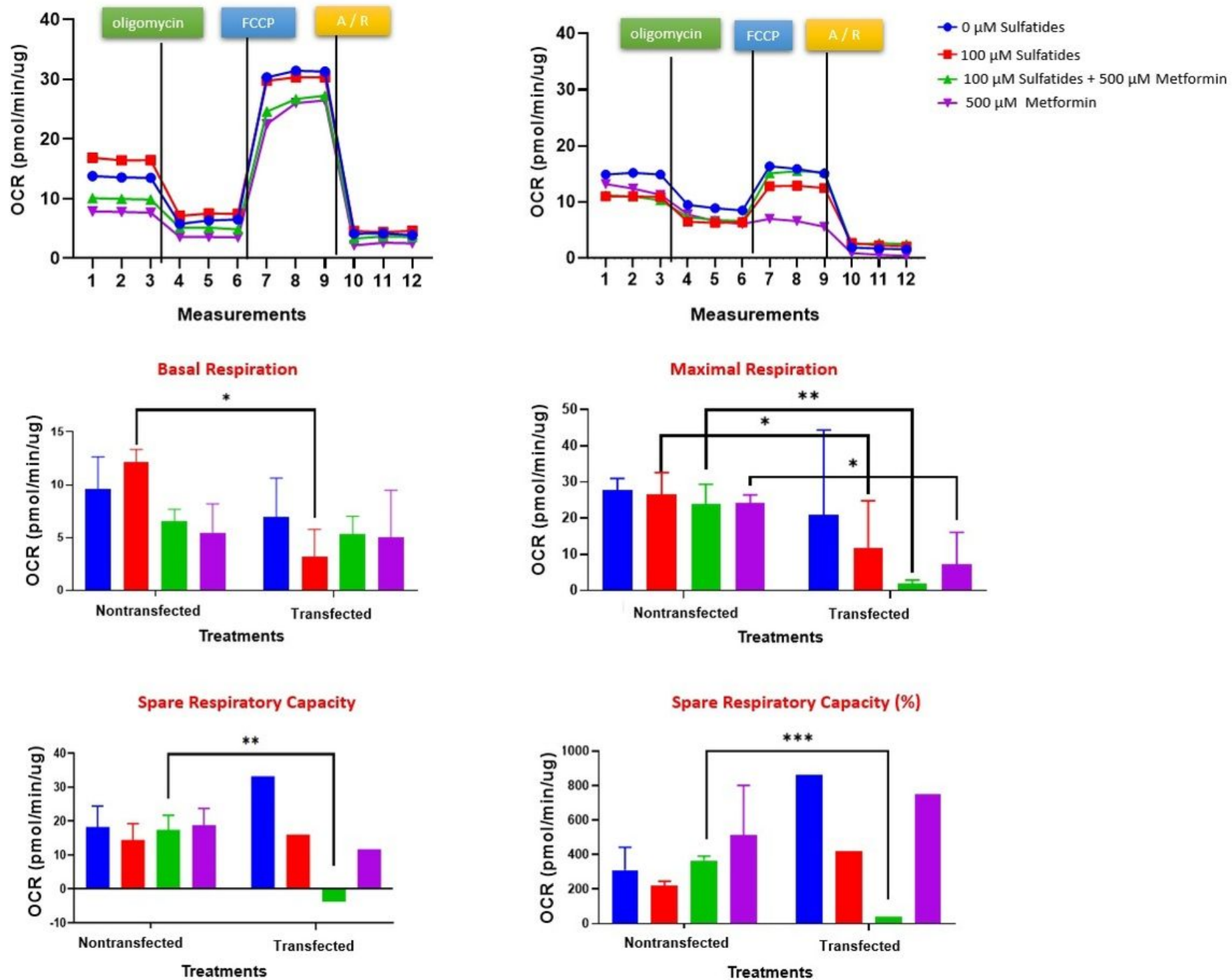

Figure 7

Mitochondrial Bioenergetics with Metformin Pull. XF Cell Mito Stress Test Kit Assay in a. nontransfected cells and b. transfected cells. Mitochondrial respiration parameters, basal respiration c. maximum respiration d. maximum respiration, e. normal reserve breathing capacity, f. and in percentage. Data are representative of two independently conducted trials. *: $p<0.05$, **: $p<0.01$, ***: $p<0.001$. 

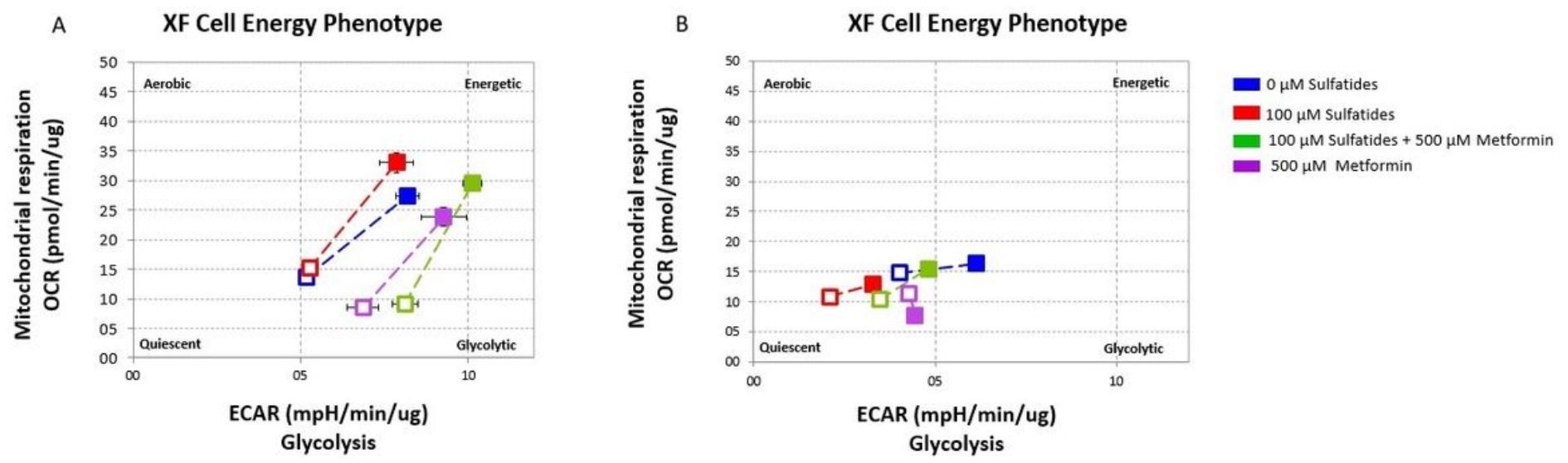

Figure 8

Phenotypic map in metformin treatment. A. Nontransfected Schwann cells. B. Transfected Schwann cells.

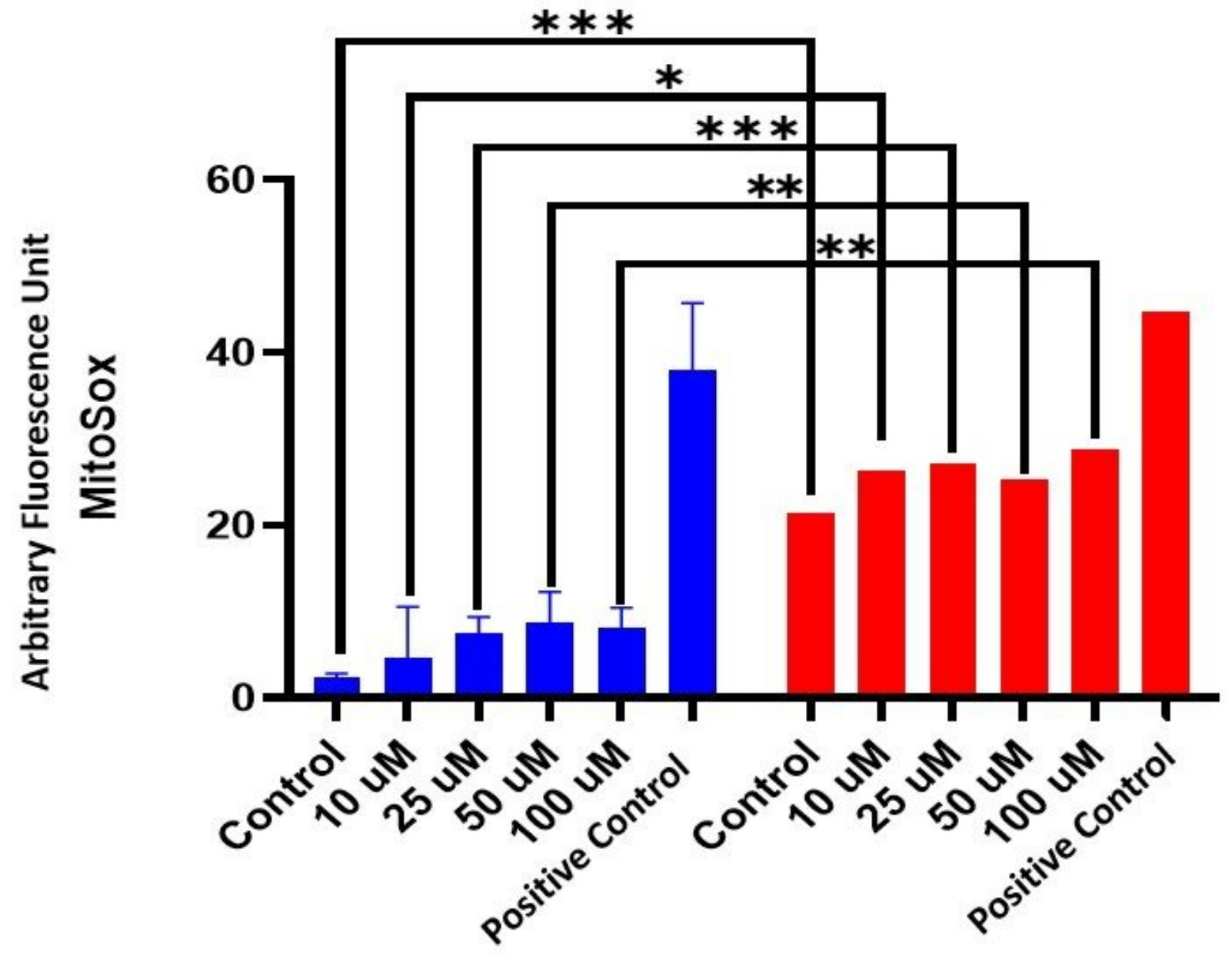

Treatments

- Nontransfected Schwann Cell Transfected Schwann Cells

Figure 9 
Quantification of the mitochondrial superoxide anion in Schwann cells. Statistical significance was calculated by applying the student's test. $*$ : $p<0.05, * *$ : $p<0.01$, $* \star *: p<0.001$, of each of the concentrations compared between transfected cells and nontransfected cells.

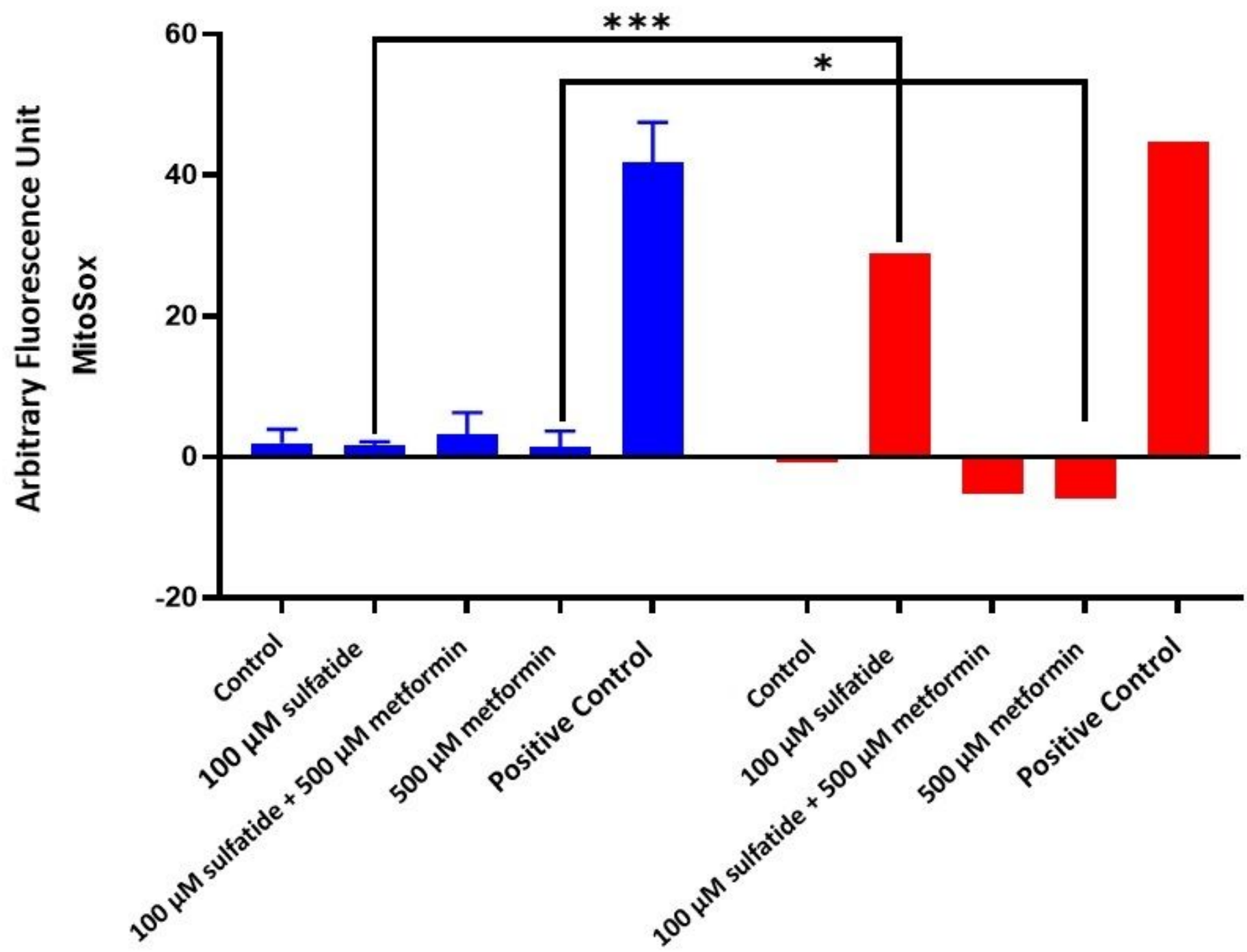

Treatments

- Nontransfected Schwann Cell

Transfected Schwann Cells

Figure 10

Decreased mitochondrial superoxide production. Statistical significance was calculated by applying the student's test. $*: p<0.05, * \star *: p<0.001$, of each of the concentrations compared between transfected cells and non-transfected cells. 